Available online on 15.02.2019 at http://jddtonline.info
Journal of Drug Delivery and Therapeutics
Open Access to Pharmaceutical and Medical Research
(c)11-18, publisher and licensee JDDT, This is an Open Access article which permits unrestricted
non-commercial use, provided the original work is properly cited

Open $\odot$ Access

Research Article

\title{
A Study on Establishment of Phytochemical Analysis of Quality Parameters and Fluorescence Analysis of Costus spicatus- rhizome extract Medicinal Plants a Well Known Tropical Folklore Medicine
}

\author{
Azhagumadhavan S, Senthilkumar S, Padma M, Sasikala P, Jayaseelan T and Ganesan S* \\ PG \& Research Department of Zoology \& Biotechnology, A.V.V.M. Sri Pushpam College (Autonomous) Poondi, Thanjavur - 613503, India.
}

\begin{abstract}
Objective: To evaluate the diagnostic pharmacognostical characters of Costus spicatus in rhizomes extract along with their physico-chemical parameters and fluorescence analysis.

Methods: The pharmacognostical characters were determined in terms of macroscopy, microscopy, Powder microscopy, rhizome constant, fluorescence analysis and Preliminary phytochemical investigation.

Result: The fluorescence characteristics of rhizome powdered extracts were determined under UV radiation of long and short wavelengths and ordinary visible light. When the powdered drug and extracts were treated with different reagents and observed under UV and ordinary light, they emitted various colour radiations. The colour change for the rhizome powder and individual extract were distinctive and reproducible revealing the solvent properties to the phytoconstituents and data is present. The moister content was calculated through the loss on drying method and was found to be $1.43 \%$. The swelling and foaming index values were recorded. The phytochemical investigation indicates the presence of the organic phytoconstituents such as alkaloids, carbohydrate, flavonoids, protein, amino acids, phenols, tannin, glycosides, steroids and inorganic constituents like iron, phosphate, sulphate and chlorides.

Conclusion: Various pharmacognostical and physicochemical parameters have pivotal roles in identification, authentication and establishment of quality parameters of the species.
\end{abstract}

Keywords: Costus spicatus, Physico-Chemical parameters and fluorescence analysis.

Article Info: Received 10 Jan 2019; Review Completed 02 Feb 2019; $\quad$ Accepted 06 Feb 2019; Available online 15 Feb 2019

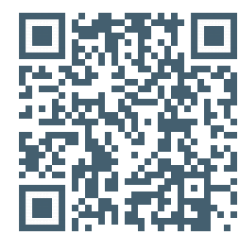

Cite this article as:

Azhagumadhavan S, Senthilkumar S, Padma M, Sasikala P, Jayaseelan T, Ganesan S, A Study on Establishment of

Phytochemical Analysis of Quality Parameters and Fluorescence Analysis of Costus spicatus- rhizome extract Medicinal

Plants a Well Known Tropical Folklore Medicine, Journal of Drug Delivery and Therapeutics. 2019; 9(1-s):240-243

DOI: http://dx.doi.org/10.22270/jddt.v9i1-s.2329

*Address for Correspondence:

Dr. Ganesan Sivamani, Assistant Professor (SG), PG \& Research Department of Zoology and Biotechnology, A.V.V.M.Sri Pushpam College (Autonomous), Poondi - 613 503, Thanjavur Dt., Tamilnadu, India.

\section{INTRODUCTION}

Diabetes mellitus (DM) is a common metabolic disorder occurring due to a lack of insulin or due to the presence of factors that oppose the action of insulin. Two broad categories of DM are designated as type1and type2 DM. Type1 DM results from autoimmune, cell destruction which leads to insulin deficiency. Distinct genetic and metabolic defects in insulin action and/or secretion gives rise to the common phenotype of hyperglycemia in type $2 \mathrm{DM}$. DM leads to both acute and chronic complications which affect most of the vital organs of our body, usually even before DM could be diagnosed. The worldwide prevalence of DM has been rising in dramatically over the past two decades, from an estimated 30 million cases in 1985 to 285 million in 2010. Based on current trends, $>360$ million individuals will have DM by the year 20301 . Diabetic is characterized by a state of chronic hyperglycemia (peripheral insulin resistance), glucosuria, polyurea, polydipsia (excessive thirst), polyphagia (constant hunger), sudden weight loss, ketoacidosis, and ketonuria (urinary ketones) etc. ${ }^{2}$. The observed that DM occurs at a younger age in developing countries. In the developed world, most diabetics are over 65 years while in developing countries, the majority in the age group of 45 to 64 - another development of enormous public health implications 3 . Herbal medications have been used for the treatment of a variety of ailments, a huge number of population in the world is entirely dependent on traditional medicines 4 . Medicinal plants still play a key role in world health as they are a rich source of many natural inhibitors and pharmacologically active compounds. Many of these substances structurally resemble biological compounds, and this similarity is the basis of their physiological action ${ }^{5}$. 
Ethnopharmacological surveys have established that C. spicatus leaf extract of decoctions, as well as aqueous or alcoholic infusions, are commonly used for the treatment of renal calculi, cutaneous ulcers, infections, inflammation, urethritis, gonorrhoea and leucorrhoea ${ }^{6}$ Currently available therapy for diabetes includes insulin and various oral hypoglycaemic agents such as sulfonylureas, metformin, glucosidase inhibitors, troglitazone, etc. But these are reported to produce serious adverse side effects such as liver problems, lactic acidosis and diarrhoea ${ }^{7}$. A large number of anti-diabetic medicines are available in the pharmaceutical market for diabetes and its related complications; however, currently, no effective therapy is available to Costus species cure the disease. However, due to unwanted side effects, the efficacies of these compounds are debatable and there is a demand for new compounds for the treatment of diabetes 8-9 Despite the introduction of hypoglycemic agents from natural and synthetic sources. Many in the Indian medicinal plants have been useful to successfully manage Diabetes mellitus. One of the great advantages of medicinal plants is that these are readily available and have very low side effects. The Plants sourced of drugs and many currently available drugs have been derived directly or indirectly from them. The ethnobotanical information reports about 800 plants species that may possess anti-diabetic plants potential 10. Irrespective of the recent phytochemistry and pharmacological research, till now no pharmacognostic work has been carried out on this species. The present investigation used different pharmacognostic and phytochemical parameters to supplement the identification and standardization information.

\section{MATERIAL AND METHODS}

\section{Collection, Identification and Authentication of plant species:}

The plant, Costus spicatus were collected from the Saliyamangalam and Thanjavur district, Tamilnadu, India. It was taxonomically identified and authenticated by Rev Dr. S. John Britto SJ, Director, The Rapinat Herbarium and Centre for Molecular Systematics, St. Joseph's College (Autonomous), Tiruchirappalli, Tamilnadu, India. The voucher specimens are deposited at the Rapinat herbarium and the voucher number is SAM 001.

\section{Plant material}

The rhizome was dried under shade, mechanically reduced to moderate coarse powder and stored in amber coloured airtight containers. Fresh rhizome was used for the macroscopical and microscopical evaluation. Coarse form of drug was employed for determination of physicochemical parameters like moisture content, ash values, swelling index, foaming index, foreign organic matter, extractive values, qualitative and fluorescence analysis.

\section{Macroscopic and microscopic analysis}

The organoleptic characteristics such as shape, size, base and margin, venation of the leaves, taste and odour of the rhizome of $C$. spicatus were determined. The macroscopy, microscopy and powder characteristics of aerial part of plant were studied according to the standard methods.11,12. Rhizomes constants viz. stomatal index and stomatal number were also studied according to the standard procedures 11 . Stomatal indices of both adaxial and abaxial epidermis in 1 $\mathrm{mm}^{2}$ rhizome surface was determined and recorded by using camera lucida and stage micrometer.

\section{Physico-chemical analysis}

Air dried rhizome was used for the quantitative determination of ash values, extractive values, moisture content, swelling index, foaming index and foreign organic matter, via standard methods. ${ }^{12-15}$. The total ash value for a crude drug is not always reliable, since there is a possibility of presence of non-physiological substances such as earthy matters. So, the parameters such as acid insoluble, water soluble and sulphated ash values were performed. Extractive values with petroleum ether, chloroform, ethyl acetate, ethanol and water were also determined. The fluorescence analysis is a tool for the determination of constituents in the plant that gives a definite idea of the chemical nature. Fluorescence analysis of rhizome powdered and various extracts was carried out by the standard method ${ }^{16}$.

\section{Preliminary phytochemical screening}

Preliminary phytochemical screening was performed using standard procedures 11,12,13. The extracts obtained from different solvents were subjected to identification tests for the detection of different phytoconstituents through organic and inorganic elements analysis, via the method of Khandelwal ${ }^{11 .}$

\section{RESULT}

\section{Macroscopic characters}

Costus spicatus rhizome grows to a length of approximately 1 $\mathrm{ft}(30 \mathrm{~cm})$ and a width of approximately 4 in $(10 \mathrm{~cm})$. It produces a short red cone, from which red-orange flowers emerge one at a time. In botanical literature, has often been misidentified as Costus spicatus. Both species are common in cultivation. In Dominican folk medicine, a herbal tea made from the rhizomes of $C$. spicatus is used to treat diabetes (Table: 1) (hyperglycemia).

\section{Physico-chemical analysis}

The results of physicochemical parameters such as total ash, acid insoluble ash, water-soluble ash and sulphated ash are shown in Sulphated ash value $(12.5 \%)$ was lower than the total ash value (13.4\%). The acid insoluble and water soluble ash values were $2.5 \%$ and $9 \%$, respectively. Further, the results also showed that moisture content, swelling index and foaming index were found to be $1.43 \%, 0.7 \mathrm{~cm}$ and less than 100 respectively while foreign organic content was found to be nill. (Table 2) The extractive values for various solvents such as ethanol, methanol, water, chloroform, ethyl acetate and, petroleum ether were found to be $4 \%, 3 \%, 11 \%$, $3 \%, 2 \%$ and $5 \%$ respectively.

Table 1: Ash values of $C$. spicatus rhizome extract

\begin{tabular}{|l|l|l|}
\hline S. No. & Parameters & Values \\
\hline 1 & Total Ash & $13.4 \%$ \\
\hline 2 & Acid Insoluble Ash & $2.5 \%$ \\
\hline 3 & Water Soluble Ash & $9.0 \%$ \\
\hline 4 & Sulphated Ash & $12.5 \%$ \\
\hline
\end{tabular}

Table 2: Moisture content, foreign organic matter, foaming index and swelling index of $C$. spicatus rhizome extract

\begin{tabular}{|l|l|l|}
\hline S. No. & Parameters & Values \\
\hline 1 & Moisture Content & $1.43 \%$ \\
\hline 2 & Foreign Organic Matter & Nil \\
\hline 3 & Foaming Index & Less than 100 \\
\hline 4 & Swelling Index & $0.7 \mathrm{~cm}$ \\
\hline
\end{tabular}


Table 3: Extractive values of $C$. spicatus rhizome extract

\begin{tabular}{|l|l|l|}
\hline S. No. & Solvent & Values\%(w/w) \\
\hline 1 & Ethanol & 4 \\
\hline 2 & Methanol & 3 \\
\hline 3 & Water & 11 \\
\hline 4 & Chloroform & 3 \\
\hline 5 & Ethyl Acetate & 2 \\
\hline 6 & Petroleum Ether & 5 \\
\hline
\end{tabular}

The fluorescence characteristics of crude powdered drugs and various extracts were determined under UV radiation of long and short wavelengths and ordinary visible light. When the powdered drug and extracts were treated with different reagents and observed under UV and ordinary light, they emitted various colour radiations. The colour change for the crude powder and individual extract were distinctive and reproducible revealing the solvent properties to the phytoconstituents and data is present (Table 3).

\section{Preliminary phytochemical screening}

The phytochemical profile of the plant revealed the presence of alkaloids, carbohydrates, flavonoids, proteins, amino acids, phenols, tannins, glycosides and steroids as organic phytoconstituents. (Table 4) Qualitative analysis of various inorganic elements revealed the presence of iron, sulphates, phosphates and chlorides.

Table 4: Fluorescence studies of $C$. spicatus rhizome extract

\begin{tabular}{|l|l|l|l|l|}
\hline S.NO & Analysed phytochemical factor & Visible Light & $\begin{array}{l}\text { Short UV } \\
\mathbf{2 5 4 n m}\end{array}$ & $\begin{array}{l}\text { Long UV } \\
\text { 365nm }\end{array}$ \\
\hline 1 & Plant powder (pp) & Light Brown & Black & Dark Black \\
\hline 2 & PP with water & Light Brown & Light Brown & Brown \\
\hline 3 & PP with Hexane & Light Brown & Dark Brown & Brown \\
\hline 4 & PP with Chloroform & Light Brown & Creamish white & Creamish Yellow \\
\hline 5 & PP with Methanol & Brown & Yellow & Black \\
\hline 6 & PP with acetone & Brown & Dark Black & Brown \\
\hline 7 & PP with IN Sodium hydroxide in water & Dark Brown & Brownish -Yellow & Dark Yellow \\
\hline 8 & PP with IN Hydrochloric acid & Light Brown & Off White & Light Brown \\
\hline 9 & PP with sulphuric acid with an equal amount of water & Black & Dark Brown & Black \\
\hline 10 & PP with Nitric acid diluted with an equal amount of water & Orangish Yellow & Dark Brown & Brown \\
\hline
\end{tabular}

Table: 5 Qualitative analysis of photochemical analysis C.spicatus in rhizomes extract

\begin{tabular}{|l|l|c|c|l|l|l|l|}
\hline S.No & $\begin{array}{l}\text { Analysed } \\
\text { photochemical factor }\end{array}$ & Ethanol & Methanol & Water & Chloroform & EthylAcetate & $\begin{array}{l}\text { Petroleum } \\
\text { Ether }\end{array}$ \\
\hline & Tannin & ++ & + & + & + & + & - \\
\hline & Phlobatannins & + & - & ++ & + & + & + \\
\hline & Saponin & +++ & + & ++ & + & - & - \\
\hline & Flavonoids & + & ++ & - & + & - & + \\
\hline & Steroids & - & - & + & ++ & - & + \\
\hline & Terpenoids & ++ & + & + & - & ++ & + \\
\hline & Triterpenoids & + & + & - & + & - & + \\
\hline & Alkaloids & +++ & ++ & + & + & - & + \\
\hline & Carbohydrate & + & - & + & - & ++ & - \\
\hline & Protein & ++ & + & ++ & - & + & - \\
\hline & Anthraquinone & + & + & + & - & - & + \\
\hline & Polyphenol & ++ & + & ++ & ++ & + & - \\
\hline & Glycoside & + & + & - & + & - \\
\hline
\end{tabular}

+ Positive, - Negative

Table 6: Qualitative analysis of Inorganic elements test of C.spicatus in rhizome extract

\begin{tabular}{|l|l|c|}
\hline S.No & Inorganic elements & Result \\
\hline 1 & Calcium & - \\
\hline 2 & Magnesium & - \\
\hline 3 & Sodium & + \\
\hline 4 & Potassium & - \\
\hline 5 & Iron & + \\
\hline 6 & Sulphate & + \\
\hline 7 & Phosphate & + \\
\hline 8 & Chloride & + \\
\hline 9 & Nitrate & + \\
\hline
\end{tabular}

+ Positive, --- Negative 


\section{DISCUSSION}

To quality control of herbal formulation is of paramount importance in justifying their acceptability in the modern system of medicine. C.spicatus has many medicinal and Therapeutic action and scientifically validated documents. The present investigation deals with all the physicochemical and pharmacognostical perspectives of the rhizome. (Table 5) The was concluded from physicochemical parameters that total ash value was found the highest $(13.4 \%)$, While acid insoluble ash was lowest $(2.5 \%)$. Cold extractive values were related the percentage yield of aqueous extract was highest $(11.0 \%)$ followed by petroleum ether $(5.0 \%)$, ethanol (4.0\%), Chloroform (3.0\%), and the lowest percentage yield was ethyl acetate $(2.0 \%)$. The moisture content was calculated loss dry methods and was found the $1.43 \%$. (Table:6).The swelling and foaming index value are recorded to be $0.7 \mathrm{~cm}$ less than 100 respectively. The phytochemical investigation indicates the presence of organic phytoconstituents such as alkaloids, carbohydrates, flavonoids, protein, amino acids, phenol, tannins, glycosides, steroids and inorganic constituents like iron, phosphate, sulphate and chlorides.

\section{CONCLUSION}

Various pharmacognostical and physicochemical parameters have pivotal roles in identification, authentication and establishment of quality parameters of the species.

\section{REFERENCES}

1. Fauci AS, Kasper DL, Braunwald E, Hauser SL, Longo DL, Jameson JL, Loscalzo J, editors. Harrison's Principles of Internal Medicine. 17th Edition. New York. McGraw Hills; 2008. Available at: http://www.accessmedicine.co.

2. Ronald, K.C., 1994. Pathophysiology of diabetes mellitus: An overview, 2nd Edition (Mac Millan Publishing Co., New York) 43.

3. Kokiwar PR, Gupta S, Durge PM. Prevalence of diabetes in a rural area of central India. Int J DiabDev Ctries. 2007; 27(1):8-10.
4. Ishani A.M. Kouhsari S.M. Mohammadi S. Vacciniumarctostaphylos, a common herbal medicine in Iran: a molecular and biochemical study of its antidiabetic effects on alloxan-diabetic Wistar rats. J Ethnopharmacol. 2011; 133:67-74.

5. Havsteen B. Flavonoids, a class of natural products of high pharmacological potency. Biochem Pharmacol. 1983; 32:1141-1148.

6. Carriconde C, Morais D, Von Fritschen M, et al. Plantasmedicinais e alimentícias. Olinda, Brazil: CentroNordestino de Medicina Popular. Universidade FederalRural de Pernambuco. 1996.

7. Rajalakshmi M, Eliza J, Priya CE, Nirmala A, Daisy P.Antidiabetic properties of Tinosporacordifoliastemextracts on streptozotocininduced diabetic rats. AfrJPharmPharmacol 2009; 3(5):171-180.

8. Moller DE. New drug targets for type 2 diabetes and the metabolic syndrome. Nature 2001; 414:821-827.

9. Oubre AY, Carlson TJ, King SR, Reaven GM. From plant to the patient: an ethnomedical approach to the identification of new drugs for the treatment of NIDDM. Diabetologia 1997; 40:614-617.

10. Liu IM, Tzeng TF, Liou SS, Lan TW. Improvement of insulin sensitivity in obese Zuckerratsbymyricetin extracted from Abelmoschusmoschatus. Planta Med 2007; 73:1054-1060.

11. Khandelwal KR. Practical pharmacognosy techniques and experiments. New Delhi: Nirali Prakashan 2002; p. 15-163.

12. Kokate CK. Practical Pharmacognosy. 1st ed. New Delhi: Vallabh Prakashan; 2005. p. 111.

13. The British Pharmacopoeia Commission. British Pharmacopoeia. European Commission. New Delhi: Department of health, social services and public safety, medicine and health care predict regulations agency; 2010, A-2.88-2.89.

14. The government of India, Ministry of Health and Family Welfare. The Ayurvedic Pharmacopoeia of India Vol-3, Part-1. 1st ed. New Delhi: Ministry of Health and Family Welfare; 2001, p. 233-251.

15. Trease GE, Evans WC. Pharmacognosy. 15th ed. Amsterdam: Elsevier; 2002, p. 95-105.

16. Kumar D, Gupta J, Kumar S, Arya R, Kumar T, Gupta G. Pharmacognostic evaluation of Cayratia trifolia (Linn.) leaf. Asian Pac J Trop Biomed 2012; 2(1):6-10. 